\title{
Assessing the team environment for knowledge sharing: an empirical analysis
}

\author{
Celia Zárraga and Jaime Bonache
}

\begin{abstract}
The self-managed work team is an organizational structure that is much used by companies today. It is put forward as the most appropriate setting for the creation and transfer of knowledge, while protecting the source of competitive advantage. However, achieving efficiency in a work team is not without its difficulties. The literature indicates that a suitable climate minimizes these. In this study, we analyse, both theoretically and empirically, the components of that climate as well as some organizational initiatives that favour its presence. The empirical study was carried out on a sample of 363 individuals working in self-managed teams within companies, mostly multinationals, located in Spain.
\end{abstract}

Keywords Self-managed work teams; transfer and creation of knowledge; high care.

\section{Introduction}

In recent years, the economies of developed countries have undergone a series of structural changes resulting in changes in what is strategic for organizations. As opposed to physical assets, which have been the traditional basis for obtaining competitive advantage, knowledge assets are what permit today's organizations to achieve better results than their competitors (Miller and Shamsie, 1996). Based on that fact, many organizations have abandoned the traditional form of structuring their operations, with the aim of strengthening those management practices that allow them to generate and protect their knowledge. In this context, the 1990s saw a notable increase in one of those practices, namely, the establishment of self-managed teams (Kirkman and Shapiro, 1997; 2001; Kirkman et al., 2001; Nicholls et al., 1999). These are non-hierarchical work groups that are responsible and accountable for outcomes in the organization (Moravec et al., 1998). According to the 1995 study by Lawler et al., 68 per cent of the Fortune 1000 made use of this type of team.

However, despite their wide use, criticism and negative aspects associated with these teams are beginning to appear (Gibson and Tesone, 2001). Along those lines, it has been said that self-managed teams do not always produce the desired improvement in performance (Chaston, 1998). Furthermore, some reluctance on the part

Celia Zárraga, Universidad de Las Palmas de Gran Canaria, Edificio Departamental de la Facultad de Ciencias Económicas y Empresariales. Módulo C, Campus Universitario de Tafira, E-35017 Las Palmas de Gran Canaria, Spain (tel: + 34928 458117; fax: + 34928 451829; e-mail: celia@empresariales.ulpgc.es). Jaime Bonache Universidad Carlos III de Madrid, C/ Madrid, 126, E-28903 Getafe, Madrid, Spain (tel: +34 91 6249578; fax: + 3491 6249313; e-mail: bonache@emp.uc3m.es). 


\section{The International Journal of Human Resource Management}

of the members to share their knowledge with the others has been indicated (Cabrera and Cabrera, 2002; Moravec et al., 1997). We can see that these two problems, although they are separate, are connected, since, if the different members of the team do not share their knowledge, the overall performance of the team will deteriorate.

These problems make it clear that self-managed teams do not always function. Only under certain conditions will the desired transfer of knowledge, and consequently the desired improved performance, take place. The literature points out the diversity of these conditions. Pfeffer (1999) states that it is necessary for the team members to participate in the selection of new members, to enjoy job security, to be encouraged by means of group incentives (for example, profit-sharing, gain-sharing) or to be trained how to work in a team. Other authors (Baron and Kreps, 1999; Cabrera and Cabrera, 2002) insist that, in order to overcome the individual's reluctance to share knowledge with the group, it is also essential to modify the policies of appraisal and professional development in such a way that not only are those who produce rewarded, but also those who exchange ideas and share their knowledge.

It is considered that those and other initiatives encourage individuals to share their knowledge and create other new knowledge, since they lead to a suitable atmosphere or climate within the group. That climate has been defined in various ways: Lawler (1992) called it 'high involvement', Von Krogh (1998), taking works of philosophy as reference, speaks of 'high care'. Anyway, such a climate is always thought of as a 'black box'. Although there are some studies that analyse this, they have mostly been carried out in the context of non-profit-making organizations (e.g. Foner, 1995; Noddings, 1984; Sarason, 1985). The fact is that there is no empirical evidence analysing it within profitmaking organizations, which, of course, companies are, that confirms its effect on the transfer and creation of knowledge.

In this work, we aim to fill that empirical gap. Basing ourselves on the knowledge management literature, we begin by offering an integrated model that identifies both the climate that must exist within a team in order for it to produce the transfer and creation of knowledge and the organizational initiatives that facilitate it. Then we will check that model on a large sample of self-managed teams in various multinational companies. To be more specific, our aim is to provide an empirical model that helps companies in the important task of identifying the factors that facilitate the transfer and creation of knowledge in self-managed teams.

\section{Team environment for knowledge sharing}

As we know from Adam Smith, companies exist because, to a great extent, working together is more productive that working as individuals. The philosophy of self-managed teams consists of taking that fundamental premise of economic science to the extreme. These teams are non-hierarchical groups of individuals with experiences and knowledge both different from and complementary (Lazear, 1998) to those responsible for a work process (Wageman, 1997).

Self-managed work teams are based on two dynamic components: 1) the processes of self-management and 2) collaboration in the work (Kirkman and Shapiro, 1997). The principle underlying this type of team is that, they acquire responsibility for their work in themselves, rather than through managers, manage their own performance and change strategies whenever necessary in order to solve problems and adapt to changing conditions (Wageman, 1997). Although the empirical evidence shows that different organizations give these teams varying levels of responsibility and autonomy in carrying out their tasks (Garvin and Klein, 1993), it is usual, for example, for the group itself to 
control the allocation of tasks to its members (Cannon-Bowers et al., 1992; Hackman, 1976; Pearce and Ravlin, 1987; Wall et al., 1986; Wellins et al., 1990), to be responsible for its own quality control, purchasing, absenteeism and training (Cannon-Bowers et al., 1992; Goodman et al., 1988; Pearce and Ravlin, 1987), to receive group compensation (Goodman et al., 1988; Pearce and Ravlin, 1987) and so on.

Many authors have pointed out various advantages, including higher productivity (Cohen and Ledford, 1994; Goodman et al., 1988; Kirkman and Rosen, 1999; Trist et al., 1977; Wellins et al., 1990), quality (Cohen and Ledford, 1994; Wellins et al., 1990), customer satisfaction (Kirkman and Rosen, 1999; Wellins et al., 1990), safety (Cohen and Ledford, 1994; Goodman et al., 1988; Trist et al., 1977), job satisfaction (Cordery et al., 1991; Wall et al., 1986) and organizational commitment (Cordery et al., 1991; Garzo and Stanwyck, 1997). Although these types of advantage may explain the ever greater use of these teams, the increase is also justified from the perspective of knowledge management. In fact, organizing the work in this way can naturally lead to one of the traditional advantages of working in a team, the complementariness of its members' knowledge (Lazear, 1998). Since such knowledge is idiosyncratic, relevant to the other members and transferred from some individuals to others, a synergy will occur, giving rise to new knowledge of a higher agency level: group knowledge (Wright et al., 1994).

What happens in this type of team is that a kind of collective knowledge is developed which requires the transfer and integration of the individuals' knowledge (Grant, 1996a; 1996b, 1997, 2001; Hedlund, 1994; Nonaka and Takeuchi, 1995) and, although in the end it resides in the individuals, it is more than the sum of what each of them knows or can do (Becker and Murphy, 1992). ${ }^{1}$ No single individual can manage to carry out all the activities necessary to produce improvements and innovations in the collective work process. Only by combining individuals with different and complementary skills and perspectives, and by achieving co-operation among them, can this process be carried out and improvements and innovations made (Grant, 1996b; Swan et al., 1999).

This collective type of knowledge is not only more appropriate in many cases, but also more strategically interesting than the merely individual type (Barney and Wright, 1998). In fact, if the company depends on the work or innovations of individuals occupying highly visible positions, their move to the competition means the loss of competitive advantage. If the company wishes to retain them, it will have to do so by increasing their salary to the value of the rents they generate, and, therefore, those rents do not go to the company (Wright et al., 1994). On the other hand, when the work and innovations are the result of teamwork, the competitive advantage is better protected. Moreover, given that the team's output is greater than the sum of its members' individual outputs, it is difficult, if not impossible, for the competition to identify the specific source of the team's success (there is causal ambiguity). Furthermore, perhaps such success is due to the trust and good relationships between all the team members, which is a complex social asset that takes time to build and is not transferable to other organizations. In such circumstances, the competition can choose to contract the entire team. However, perhaps the team was so effective in the previous company because of its unique background or its special relationships with other teams, which are specific assets that cannot be acquired on the market. In other words, the causal ambiguity, social complexity and specificity associated with the collective knowledge of self-managed teams provide an advantage that is more difficult to imitate than mere individual work or innovation is.

Although working and innovating in a group is more appropriate and advantageous to the company, it is more complex than doing so at an individual level. What is more, work 
RIJH 100320—13/8/2003-KRISHNAMURTHI-79542

\section{The International Journal of Human Resource Management}

in a team has the potential to create a situation in which knowledge is not shared. In fact, taking the social dilemma theory as a reference, it has been pointed out that teams in which knowledge has to be exchanged and shared present the problems typical of common assets (Cabrera and Cabrera, 2002). A common asset is a shared resource, made up of the voluntary contributions of some of the members of a collective, and from which all the members benefit, whether they have contributed or not (Connolly and Thorn, 1990). These assets provide an incentive for some members to take advantage of the collective. In fact, if everybody contributes and shares their knowledge except one, then that one will be able to benefit from collectively generated knowledge free. On the other hand, if one person is the only one to contribute and share, it may result in costs (loss of power, position of privilege, job, etc.) without obtaining any benefit in return. In that case, non-contribution is the dominant strategy, and, if everybody adopts that strategy, no type of collective knowledge will be generated (Cabrera and Cabrera, 2002). From a sociological point of view, that might explain the problems mentioned in the introduction related to the reluctance of some members of self-managed teams to share their knowledge and to the fact that improved performance is not always produced.

However, this type of problem could also be explained from an economics perspective. Nowadays, it is classic for the economics literature to refer to the 'free-rider effect' as one of the potential problems of working in teams: members who benefit 'free' from the group effort (Lazear, 1998). If no mechanism exists to avoid the presence of that effect, the other team members, who had originally contributed and shared their knowledge, will probably reach a stage when they consider it more profitable for them to act in the same way, resulting in a progressive decline in the group's overall performance.

A co-operative solution of social dilemmas and the non-appearance of free-riders occur as long as there exists in the group a climate or atmosphere that reflects the kind of relationship among its members leading to knowledge sharing and working to a common end (Baron and Kreps, 1999; Cabrera and Cabrera, 2002). If that climate or atmosphere does not exist, then interpersonal co-operation, essential for the generation of true group knowledge, will not take place. What does that atmosphere or kind of relationship consist of?

The literature on knowledge management has described that atmosphere as one of true internal collaboration among group members (Miles et al., 1998) that goes beyond mere communication and exchange of information among them (El Sawy et al., 1997). That atmosphere has been labelled in various ways. Lawler (1992) defines it as 'high involvement', while Von Krogh (1998) calls it 'high care'. It would be the 'mental' element of what Nonaka and Konno (1998) call a shared organizational context for the transfer and integration of knowledge, which also includes physical components (e.g. offices) and virtual components (e.g. e-mail).

Many of the above authors base themselves on artistic and philosophical atmospheres to characterize the dimensions making up that climate. In fact, in such atmospheres, we can find examples that offer clues about the type of relationship that must exist between collaborators for them truly to create and integrate ideas and knowledge. Jorge Luis Borges, one of the few writers who has worked in collaboration, says in his autobiography:

I have often asked myself how one manages to write in collaboration. I think that it requires both parties to forget about ego, vanity and perhaps even courtesy. Collaborators must forget about themselves and only think about the work. In fact when someone asks whether this joke or that epithet came from me or from Bioy, I honestly don't know. I've tried to 
collaborate with other friends, some of them very close, but, on the one hand, the inability to be frank, and on the other, putting up a self-defensive front made those projects impossible. (Borges, 1999:121)

Borges' text highlights the different dimensions of the climate or atmosphere of collaboration: thinking in terms of the work, not putting up a shield, forgetting courtesy, maintaining a certain emotional relationship (in his case, friendship) with the collaborator, etc.

If we switch from the artistic environment of Borges' text to that of business literature, we shall also find a series of dimensions that, although more systematic and detailed, are, curiously enough quite similar to those of that Argentine writer. Von Krogh (1998), based on Mayeroff (1971), establishes that high care will be present in the team to the extent that the following exist:

- Mutual trust The belief that the other members have the abilities of absorption (Cohen and Levinthal, 1990) and retention (Zaltman et al., 1973), both necessary to assimilate and apply the new knowledge being transferred to them (Szulanski, 1996). That belief must coincide with the recipient's certainty of the good intentions and ability of the transmitter of the knowledge.

- Active empathy Putting oneself in the other's place, understanding 'emotionally' his/her particular situation, interests and level of skills, background of success and failure and future opportunities and problems. As Nonaka and Konno (1998) state, empathy will make people feel free, leading to them sharing their feelings, experiences and mental model.

- Lenience in judgement Offering judgements and opinions of the actions or ideas of the other group members, but with clemency. This means taking into consideration the context of the action or opinion, the background and psychological state, etc., of the other member. In other words, offering feedback in an appropriate manner.

- Courage The team members must express their opinions fearlessly. In that way, the individual mental models will continuously be shared with the others and, in turn, the authors of the opinions will make an effort to analyse and reflect on them (Nonaka and Konno, 1998).

- Access to help The various members must be willing to share their knowledge with the other members. As Von Krogh (1998) states, the lack of this willingness is one of the fundamental problems of organizations at the time of sharing knowledge. This can usually be explained by a fear of losing the position of power or privilege associated with the exclusive possession of certain knowledge.

In the light of these considerations, we can establish our first hypothesis as follows:

Hypothesis 1: An atmosphere in the work team where there is mutual trust, active empathy, lenience in judgement, courage and access to help (i.e. high care) favours the transfer and creation of knowledge in the team.

\section{Initiatives for building high care}

According to a survey by KPMG $(2000),{ }^{2} 62$ per cent of the principal companies in Europe and the USA are adopting initiatives to facilitate the transfer and creation of knowledge in and between work teams. However, many of those initiatives are attempting to act, not so much in the atmosphere, or mental component, of the context in 


\section{The International Journal of Human Resource Management}

which the teams work, as in the virtual component. The latter component includes, for example, the different technology-based information systems (e.g. Intranets, data warehousing, DSS, Lotus Notes, etc.) that the company provides for the exchange of explicit knowledge.

This preponderance of technological initiatives comes as no surprise if we bear in mind that, according to the survey by KPMG, most knowledge management systems are run by the information-processing department and not by the human resources department. It can be assumed that the problem of knowledge exchange is essentially technical rather than to do with the working atmosphere. ${ }^{3}$

However, information technology alone, sophisticated as it may be, cannot make the members of a self-managed team embark on collaboration and the exchange of knowledge and experiences. Considering the social dilemmas and the free-rider effect associated with work teams, information systems, unless accompanied by other initiatives, create an incentive for non-co-operation and for some individuals to take advantage of others. For example, imagine a self-managed work team whose members issue reports, available to all employees (a common asset), that make all the knowledge that their contributions made possible explicit. Suppose that one of the members was not willing to collaborate. Applying the logic explained above, non-contribution would be the dominant strategy, and if all the members followed it, there would be an underutilization of that information system and the desired transfer of knowledge would not take place. In other words, initiatives based on information systems and technology may be a necessary condition, but in no way are they sufficient to share and create knowledge. It is necessary to consider the psychosocial context that makes the transfer of knowledge easy or difficult: the context that we try to capture in the climate variable.

If this climate, or high care, is, hypothetically, the variable essential for the transfer and creation of knowledge in work teams, it would be interesting to know what specific initiatives the company can adopt to achieve that climate. In that respect, as we stated in the introduction, the literature mentions many practices and initiatives that favour the transfer and creation of knowledge in work teams (Baron and Kreps, 1999; Cabrera and Cabrera, 2002; Pfeffer, 1999). Such initiatives suppose the creation of that climate, but this is now seen as a kind of 'black box'. For example, it is supposed that a system of appraisal and promotion that rewards individuals who share and disseminate their knowledge influences the creation of a climate that encourages that behaviour. However, we do not know which specific dimensions of that climate it affects (is it the access to help? the courage? or which?). This means that, based on the literature, we can establish a series of hypotheses about certain initiatives and the creation of high care. The specific dimensions that influence high care will be empirically determined in this work. However, it is not our intention to analyse the importance of each and every dimension, but only to centre on those usually highlighted, as follows.

\section{Team leader}

The influence of the team leader seems to be a widely analysed and extremely powerful mechanism. The traditional task of the leader is to focus and co-ordinate the different viewpoints found within the work team (Leonard and Strauss, 1997; Leonard and Sensipier, 1998). In addition to that, and following Eppler and Sukuowski (2000), team leaders must provide real and virtual spaces for communication, as well as guidelines for the team. Their function is to serve as models to the collaborators, openly sharing their information, putting themselves in others' shoes, providing feedback and showing all 
RIJH 100320—13/8/2003-KRISHNAMURTHI—79542

Zárraga and Bonache: The team environment for knowledge sharing

those attitudes and behaviours associated with a climate of 'high care'. We can now establish the second hypothesis:

Hypothesis 2: In a work team, the presence of a leader involved with the team favours high care in that team.

\section{Reward systems linked to knowledge sharing}

Reward systems indicate what the organization values and shape individuals' behaviour (Cabrera and Bonache, 1999). Traditional reward systems reward those who produce rather than those who share. Therefore, if an individual is rewarded (by promotion, for example) for what he knows and the others do not know, he is being assessed as doing his job better than his colleagues, and sharing and disseminating has a high cost to the individual. What we are dealing with, then, is lowering the cost of sharing, or, similarly, increasing the benefit associated with that type of behaviour. Along those lines (e.g. Baron and Kreps, 1999; Hilb, 1995), group incentives, promotion systems that encourage individuals to be more collaborative and $360^{\circ}$ appraisal systems are practices that help create a suitable climate for the transfer and creation of knowledge. Therefore the third hypothesis is:

Hypothesis 3: Reward systems linked to knowledge sharing favour high care in the work team.

\section{Training for team work}

Reward systems will have little effect on the members of a team if they lack the capacity to co-operate with one another. Training is an essential means of developing the capacity to co-operate and show the behaviours typical of a good climate for working in a team, namely offering constructive feedback, presenting ideas openly, understanding the viewpoints of the other members, etc. Together with the benefit of enhanced capability, which traditionally stems from training (Baron and Kreps, 1999), this type of training also has other benefits. In particular, it permits the organization to send signals about the importance of sharing and creating knowledge, to strengthen a corporate culture focused on that objective and to increase employees' commitment to that objective. In the light of those benefits, we can establish the following hypothesis:

Hypothesis 4: Training for working in a team favours high care in the work team.

\section{Social events}

Informal communication networks favour sharing both explicit and implicit knowledge (Hedlund, 1994). The outstanding example of the importance of this aspect is that of the American semiconductor industry (Almeida, 1996; Brown and McDonald, 1982; Sanexian, 1991). The culture of intra-regional communication and mobility among the companies in that industry led to sharing knowledge locally, which in turn led all the companies involved to continuous innovation (Almeida, 1996). Switching these experiences to the context of a company organized into work teams, we can identify social events, both informal (e.g. having coffee together during breaks or a drink after work) 


\section{The International Journal of Human Resource Management}

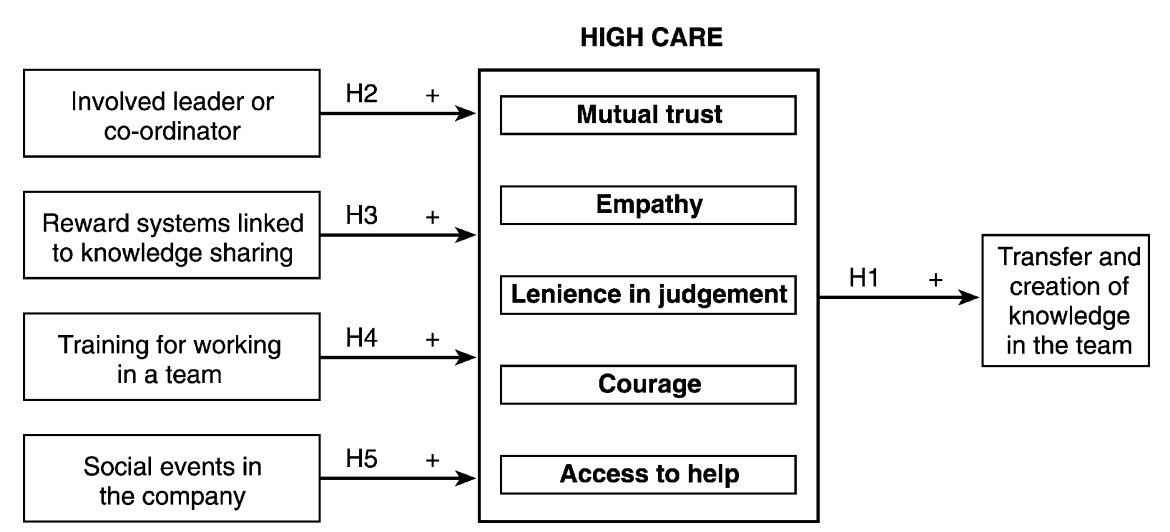

Figure 1 Establishment of hypotheses

and formal (e.g. parties and dinners organized by the company) as initiatives to create high care. Therefore, we establish the following hypothesis:

Hypothesis 5: Social events in the company favour high care in its work teams.

Figure 1 summarizes the hypotheses that we wish to check in this research.

\section{Methodology}

The method chosen to check the above hypotheses was a survey carried out by means of questionnaires. A self-administered questionnaire was sent by post or e-mail to each of the participants who, after reading it, completed it with no direct assistance from anybody involved in the research and then returned it. A pre-test was run on one of the teams in the sample, permitting us to improve some of the questions and arrive at the final version of the questionnaire.

\section{Universe and sample size}

The universe under study comprised individuals working in medium and large companies located in Spain and who carried out their jobs in self-managed teams. Since the resource under analysis is knowledge, which is found in the individual members, our attention focuses on people who work in a team, those people being the unit of analysis.

The universe, as defined, was considered infinite and, as a census of that universe was impossible, it had to be considered homogeneous. In that way, and with the aim of obtaining an assumed error of around 5 per cent, the sample had to comprise some 400 individuals.

After contacting various companies that organize the work, either partly or totally, in teams, we obtained the collaboration of twelve of them, mainly multinationals operating in Spain. The participating companies were: Alcatel España, S.A., Alstom España IB, S.A., C.A.S.A., Canarias Telecom, ENBS-Empresa Nacional Santa Bárbara, Ericsson España, S.A., Fasa Renault, Gas Natural de Álava (GASNALSA), Iberdrola, Red Eléctrica de España, S.A., Renfe and Seat, S.A. All these companies offered the participation of part of their workforce. After the six months of fieldwork (from November 2000 to April 2001,) the participation of 363 individuals was obtained, giving a sample error of 5.2 per cent. 
Most (73 per cent) of the individuals comprising the sample had at least three years experience of working in a team. The largest age group in the sample was between 35 and 50 years old (48 per cent), the remaining 52 per cent being almost equally divided between those under 35 and those over 50 . Secondary education had been completed by 45.3 per cent of the individuals, while a notable 27 per cent had higher university degrees. The remainder was almost equally split between primary education and lower university degrees.

\section{Measurements}

All the scales formulated to measure the variables being studied comprised items corresponding to statements listed on the questionnaire, which all had to be given a score on a 7-point Likert-type scale ranging from 'scarcely agree' (1) to 'completely agree' (7). ${ }^{4}$

With the aim of measuring the degree of transfer and creation of knowledge in the work team, and since there are no objective data that will indicate that degree, we chose to measure its perception from the viewpoint of the individuals comprising the sample. Some studies of teamwork (e.g. Kirkman and Rosen, 1999; Stewart and Barrick, 2000) use similar techniques to measure the results of the teams. Based on the adopted definition of the process of transfer and creation of knowledge (and in such a way that the validity of the content is assured), we formulated five statements, which, in our opinion, would constitute a valid measuring scale. Then, to facilitate the analysis and interpretation of the data, we thought suitable it to reduce its dimensions. To do this, an analysis of the principal components was carried out using varimax rotation. As a result, two dimensions, or independent factors, were detected that jointly explain 70 per cent of total variance. The first factor corresponds to the items defining the transfer of knowledge in the work team, while the other deals with the creation of knowledge in the work team. The proportions of explained variance of each of the items, expressed by means of commonalties, were good, given that all had a level of around 0.7. Finally, a reliability test was run both for the entire scale and for each of its dimensions. This was done using the Cronbach's alpha statistic (1951), the results of which indicated that we had achieved acceptable measuring instruments $(\alpha=0.7$ for the factor transfer of knowledge; $\alpha=0.6$ for the factor creation of knowledge).

To establish a scale to measure the perception of the individuals regarding the climate of their work team, ten items were designed, responding to those dimensions formulated by von Krogh and included in our model. As with the previous scale, an analysis of the principal components was carried out to reduce its dimensions. Consequently, three dimensions were obtained, jointly explaining approximately 70 per cent of total variance. Those three dimensions are: the degree of active empathy and lenience in judgement in the work team, the level of courage of the members of the work team and the degree of mutual trust and access to help in the work team. In addition, the corresponding analyses to check the reliability of the scales were carried out and the results showed their suitability. That is, Cronbach's (1951) alpha statistic was around 0.75 for each of the three detected dimensions.

Finally, to find scales to measure the perception of the initiatives for action put forward theoretically, the items corresponding to each of them were designed. In each case, a principal components analysis was carried out to ensure the uni-dimensionality of the scale used. In addition, a reliability analysis was run for each of them. The results showed that valid, reliable measurements were obtained for all the mechanisms.

Analysis

In order to check the above hypotheses, the tools for statistical analysis were Pearson's correlation coefficient and multiple regression analysis. The former measures the degree 
RIJH 100320—13/8/2003-KRISHNAMURTHI-79542

\section{The International Journal of Human Resource Management}

of linear relationship between the variables of interval or of ratio, with values ranging from -1 to +1 , and the nearer to zero this statistic is, the less the correlation between the two variables. The latter analysis examines the contribution of each of a group of independent variables to explaining another dependent variable. Each independent variable contributes to explaining a percentage of the dependent variable, and if that is significant, it is accompanied by a regression coefficient that quantifies its influence on the dependent variable.

\section{Results}

The Pearson's correlation coefficients, calculated to deal with checking the first hypothesis are shown in Table 1. It can be seen that all the dimensions of high care show significant linear relationship, for the degree both of transfer and of the creation of knowledge in the work team. However, since the components of high care, although independent, act jointly, we set out to discover their relative importance. To that end, we carried out the corresponding multiple regression analyses. As a result of those analyses (see Table 2), it was found that the most important component explaining the degree of transfer of knowledge in the work team is mutual trust and access to help $\left(\mathrm{R}^{2}=0.13\right.$ against a total $\mathrm{R}^{2}$ of 0.24$)$. The most important element of the climate explaining the degree of creation of knowledge in the work team is active empathy and lenience in judgement $\left(R^{2}=0.09\right.$ against a total $R^{2}$ of 0.13$)$. In any case, both regressions also show that high care as a whole explains a very small proportion of the variance of the processes related with knowledge in the team ( 24 per cent of the transfer and 13 per cent of the creation of knowledge). This clearly indicates the existence of other important factors favouring the process which have not been taken into account in this study. For example, the 'multi-faceted dialogue' (Leonard and Sensiper, 1998) or the 'common language' (Grant, 1996b; 1997; Nonaka and Takeuchi, 1995), which are both related to the composition of the team, are factors that have not been included in this work and would probably add to the explanation of the degree of transfer and creation of knowledge in a self-managed work team.

In order to check the other hypotheses, there was a calculation of the correlation coefficients existing between each of the variables designed to measure the management

Table 1 Degree of relationship between the climate and the transfer and creation of knowledge in the team

\begin{tabular}{llll}
\hline & $\begin{array}{l}\text { Degree of active } \\
\text { empathy and lenience } \\
\text { in judgement in } \\
\text { the team }\end{array}$ & $\begin{array}{l}\text { Degree of courage } \\
\text { of the members } \\
\text { of the work team }\end{array}$ & $\begin{array}{l}\text { Degree of mutual } \\
\text { trust and access } \\
\text { to help in the } \\
\text { work team }\end{array}$ \\
\hline $\begin{array}{c}\text { Degree of transfer } \\
\text { of knowledge } \\
\text { in the work team }\end{array}$ & $0.1598(0.005)^{*}$ & $0.2984(0.000)^{*}$ & $0.3580(0.000)^{*}$ \\
$\begin{array}{l}\text { Degree of creation } \\
\text { of knowledge } \\
\text { in the work team }\end{array}$ & $0.3015(0.000)^{*}$ & $0.1729(0.002)^{*}$ & $0.1223(0.032)^{*}$ \\
\hline
\end{tabular}

$*$ Level of significance $<0.05$. 
RIJH 100320—13/8/2003-KRISHNAMURTHI—79542

Zárraga and Bonache: The team environment for knowledge sharing

Table 2 Relative importance of the components of the climate to the transfer and creation of knowledge in the work team

\begin{tabular}{|c|c|c|c|}
\hline Component of the climate & $\beta(p)$ & Adjusted $R^{2}$ & Accumulated $R^{2}$ \\
\hline \multicolumn{4}{|c|}{ DEPENDENT VARIABLE: Transfer of knowledge in the work team } \\
\hline $\begin{array}{l}\text { Degree of mutual trust and access to } \\
\text { help in the work team }\end{array}$ & $0.3445(0.000)$ & 0.125 & 0.125 \\
\hline $\begin{array}{l}\text { Degree of courage of the members } \\
\text { of the work team }\end{array}$ & $0.3179(0.000)$ & 0.087 & 0.212 \\
\hline $\begin{array}{l}\text { Degree of active empathy and lenience } \\
\text { in judgement in the work team }\end{array}$ & $0.1666(0.001)$ & 0.025 & 0.237 \\
\hline \multicolumn{4}{|c|}{ DEPENDENT VARIABLE: Creation of knowledge in the work team } \\
\hline $\begin{array}{l}\text { Degree of active empathy and lenience } \\
\text { in judgement in the work team }\end{array}$ & $0.3149(0.000)^{*}$ & 0.089 & 0.089 \\
\hline $\begin{array}{l}\text { Degree of courage of the members } \\
\text { of the work team }\end{array}$ & $0.2048(0.000)^{*}$ & 0.035 & 0.124 \\
\hline $\begin{array}{l}\text { Degree of mutual trusts and access } \\
\text { to help in the work team }\end{array}$ & $0.1071(0.046)^{*}$ & 0.009 & 0.133 \\
\hline
\end{tabular}

$*$ Level of significance $<0.05$.

initiatives and each dimension of high care. Table 3 shows the results, where a significant linear relationship can be seen between all of them except between the perception of training for teamwork and the degree of mutual trust and access to help in the team.

However, although practically all the initiatives have been shown to influence high care in the work team, it was interesting to discover the level of importance of that influence. Table 4 shows the results of the relevant multiple regression analyses carried out to that end. It can be seen that the most important action affecting the degree of active empathy and lenience in judgement stems from social events in the company. The most important mechanism for courage in the members of the team is that related to training for teamwork, while the degree of mutual trust and access to help was most influenced by

Table 3 Degree of relationship between the climate and management initiatives

\begin{tabular}{|c|c|c|c|}
\hline & $\begin{array}{l}\text { Degree of active } \\
\text { empathy and lenience } \\
\text { in judgement in the } \\
\text { work team }\end{array}$ & $\begin{array}{l}\text { Degree of } \\
\text { courage of the } \\
\text { members of the } \\
\text { work team }\end{array}$ & $\begin{array}{l}\text { Degree of mutual } \\
\text { trust and access } \\
\text { to help in the } \\
\text { work team }\end{array}$ \\
\hline $\begin{array}{l}\text { Leader or co-ordinator } \\
\quad \text { involved with the work team }\end{array}$ & $0.219(0.000)^{*}$ & $0.122(0.028)^{*}$ & $0.451(0.000)^{*}$ \\
\hline $\begin{array}{l}\text { Reward systems linked with } \\
\text { knowledge sharing }\end{array}$ & $0.223(0.000)^{*}$ & $0.147(0.006)^{*}$ & $0.129(0.014)^{*}$ \\
\hline Training to work in a team & $0.19(0.000)^{*}$ & $0.214(0.000)^{*}$ & $0.068(0.117)$ \\
\hline Social events in the company & $0.352(0.000)^{*}$ & $0.177(0.001)^{*}$ & $0.141(0.005)^{*}$ \\
\hline
\end{tabular}

*Level of significance $<0.05$. 
RIJH 100320—13/8/2003_KRISHNAMURTHI—79542

\section{The International Journal of Human Resource Management}

Table 4 Relative influence of the initiatives for action on the components of high care

\begin{tabular}{|c|c|c|c|}
\hline Mechanisms of action & $\beta(p)$ & Adjusted $R^{2}$ & Accumul. $R^{2}$ \\
\hline \multicolumn{4}{|c|}{ DEPENDENT VARIABLE: Degree of active empathy and lenience in judgement in the work team } \\
\hline Social events in the company & $0.315(0.000)^{*}$ & 0.121 & 0.121 \\
\hline $\begin{array}{l}\text { Leader or co-ordinator involved } \\
\text { with the work team }\end{array}$ & $0.130(0.024)^{*}$ & 0.012 & 0.133 \\
\hline $\begin{array}{l}\text { Reward systems linked to } \\
\text { knowledge sharing }\end{array}$ & $0.036(0.581)$ & - & - \\
\hline Training to work in a team & $0.048(0.427)$ & - & - \\
\hline \multicolumn{4}{|c|}{ DEPENDENT VARIABLE Degree of courage of the work team members } \\
\hline Training to work in a team & $0.214(0.000)^{*}$ & 0.043 & 0.043 \\
\hline Social events in the company & $0.108(0.087)^{* *}$ & 0.006 & 0.049 \\
\hline $\begin{array}{l}\text { A leader or co-ordinator involved } \\
\text { with the work team }\end{array}$ & $0.066(0.272)$ & - & - \\
\hline $\begin{array}{l}\text { Reward systems linked to } \\
\text { knowledge sharing }\end{array}$ & $0.055(0.446)$ & - & - \\
\hline \multicolumn{4}{|c|}{ DEPENDENT VARIABLE: Degree of mutual trust and access to help in the work team } \\
\hline $\begin{array}{l}\text { A leader or co-ordinator involved } \\
\text { with the work team }\end{array}$ & $0.451(0.000)^{*}$ & 0.2 & 0.2 \\
\hline $\begin{array}{l}\text { Reward systems linked to } \\
\text { knowledge sharing }\end{array}$ & $0.021(0.693)$ & - & - \\
\hline Training to work in a team & $-0.014(0.794)$ & - & - \\
\hline Social events in the company & $0.014(0.798)$ & - & - \\
\hline
\end{tabular}

*Level of significance $<0.05$.

$* *$ Level of significance $<0.10$.

the presence of a team leader. Moreover, it was noticed that the reward systems linked to knowledge sharing had practically no relative influence on any of the three components of high care.

At this point, it must be stressed that the mechanisms under consideration hardly provide any explanation for three components of the climate. Only 5 per cent of the total variance of the courage of the team members was explained. This makes obvious the need to study other mechanisms with greater explanatory powers.

Figure 2 summarizes the main results obtained about the combined effects of the components of high care on the transfer and creation of knowledge in the work team, as well as the effects of the management initiatives related to those components.

\section{Conclusions}

As opposed to those business practices that assume that knowledge management is a technical problem solved by the mere introduction of an efficient information system, this study, taking self-managed teams as a reference point, stresses the importance of the psychosocial variables, in particular the climate for the transfer and creation of knowledge. From that perspective, it provides empirical backing for a fact that has been widely highlighted in the recent literature on knowledge management 
HIGH CARE

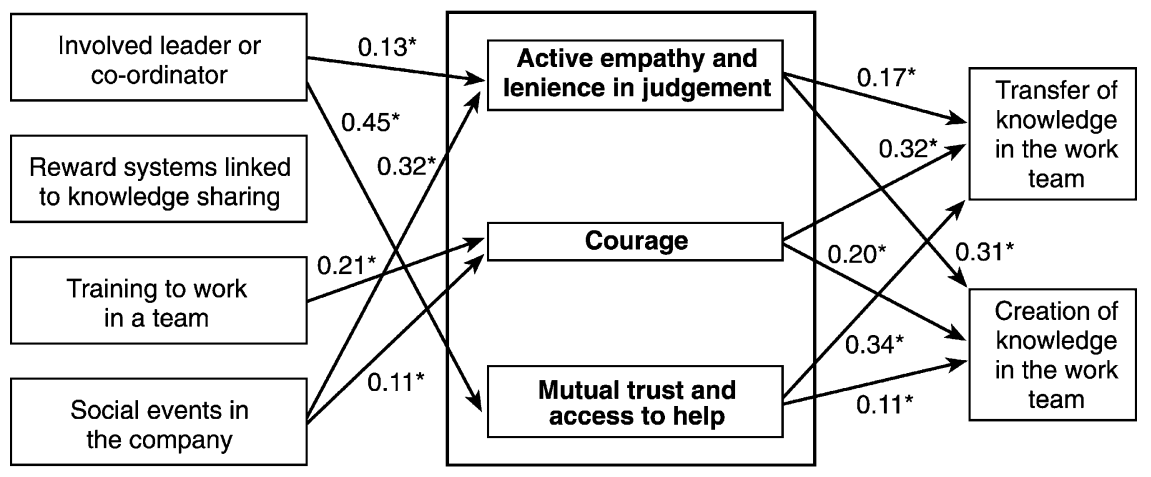

${ }^{*}$ Level of significance $<0.05$

${ }^{* *}$ Level of significance $<0.10$

Figure 2 Principal results of joint action

(e.g. Cabrera and Cabrera, 2002; Moravec et al., 1997; Nonaka and Konno, 1998; Von Krogh, 1998).

In addition, it has revealed the content of that climate, a variable that the literature has considered as a kind of 'black box', difficult to discover and analyse (Von Krogh, 1998). More specifically, it has shown how to break down that climate into three independent dimensions: active empathy and lenience in judgement, courage, and mutual trust and access to help. In fact, by using the terminology of knowledge management, this study contributes to making explicit things that have been tacitly assumed in previous models.

Nonaka and Teece (2001) state in their preface that 'because of the poor state of knowledge about knowledge management, it is important at this stage to generate new ideas and frameworks rather than focus on the rigorous testing of hypotheses'. However, without denying the appropriateness of continuing to delve into the theoretical approaches to knowledge management, our study highlights the need for empirical studies that help to refine what has been discussed at a purely theoretical level in the literature. Moreover, the most common tendency when tackling empirical studies about constructs with a weak theoretical basis, such as those we set out in this work, is to resort to qualitative methodology (Bonache, 1999; Yin, 1989). However, we have opted for one of a quantitative nature. This has allowed us to generalize the results and, in fact, has provided us with some interesting evidence. On the one hand, the dimensions of the climate do not act in the same way on the transfer as they do on the creation of knowledge. Some (mutual trust and access to help) have more effect on the transfer of knowledge, while others (active empathy and lenience in judgement) have more on the creation of knowledge. Such proof has important implications in practice, since it provides a guide for organizations to know which elements of the climate in the work team should be strengthened, depending on what they wish to achieve in them (transfer versus creation).

In addition, and regarding the traditional initiatives to generate high care in work teams, we have seen that they do not all act in the same way. The use of reward systems linked to knowledge sharing, acting alone, favours all the dimensions of the climate, but, together with other initiatives, its relative influence is negligible. On the other hand, the figure of 
RIJH 100320—13/8/2003-KRISHNAMURTHI-79542

\section{The International Journal of Human Resource Management}

a leader involved with the team is clearly the principal factor favouring mutual trust and access to help in the work team. Training for teamwork affects mainly individuals' courage, while social events in the company especially favour active empathy and lenience in judgement among the work-team members. These results highlight the need to avoid analysing as a whole something that in reality is composed of many parts or components. Only then will it be possible to continue studying the area in depth and to offer suitable solutions to the specific problems facing the company (creation of new knowledge, transfer of knowledge between the team members, lack of trust in the team, etc.).

As much as this study makes an empirical contribution to the eminently theoretical literature on knowledge management in work teams, not only is it no more than a first step in that direction, but it also has its limitations, three of which stand out. First, the variables used for the transfer and creation of knowledge in a team, as well as the climate in the team, have been measured using purely subjective perceptions. An empirical work based on objective measurements represents an interesting challenge that will have to be faced in future research. Second, the low proportion of explained variance of the dimensions of high care clearly shows the lack of important management initiatives in the model. It is true that our objective in including those initiatives was not to give a detailed account of them, but to classify them within our model. However, given their importance, later works will have to make a complete inventory of the set of those initiatives. Finally, our selection of a sample of individuals of Spanish nationality presents a barrier to the generalization of the results of the study. From that point of view, to repeat the research in different countries and later compare the results obtained would be extremely enlightening.

That means studying in depth, both theoretically and empirically, a variable such as climate. Although this is often omitted from business practice, it is essential for organizations to make use of self-managed teams in order to face the challenge of continuous improvement demanded by today's competitive environment.

\section{Appendix 1}

\begin{tabular}{ll}
\hline Factor & Statements in the questionnaire \\
\hline & - In my work team, I have learnt new things from my \\
& colleagues that only they knew. \\
- In my work team, I have shared knowledge and & experiences from my past (in this company or \\
Degree of transfer of & in others) that only I knew. \\
knowledge in the work team & - In my work team, it is normal that, as a result of \\
& ideas contributed by a member, we have related \\
& ideas that we had never considered before, and \\
& which we go on to develop. \\
& - My work team has come up with idea/s for \\
& improvement that the company has subsequently \\
& put into operation. \\
- In my work team, we have generated many & improvements on the traditional way \\
in the work team & of doing things.
\end{tabular}


RIJH 100320—13/8/2003-KRISHNAMURTHI—79542

Zárraga and Bonache: The team environment for knowledge sharing

Appendix 1 - continued

Factor $\quad$ Statements in the questionnaire

- In my work team I try to respect and understand what the other members need.

Degree of active empathy and lenience

- In my work team, I try to understand the problems in judgement in the work team and difficulties facing my colleagues while they are doing their work.

- In my work team I am sincere in expressing my opinions about the work of my colleagues.

- In my daily work, I try new ways of performing my task, even if they are wrong at times.

- In my daily work, I make suggestions to my colleagues about how to improve their work.

Degree of courage of the members of the work team

- In my work team, I have no difficulty expressing my opinions.

- In my work team, I have the freedom to experiment with new ways of performing the tasks.

- My colleagues in the work team are valuable people with good intentions.

Degree of mutual trust and access to - In my work team, when I offer help to others, I trust that they will be able to understand and use my ideas in the best possible way.

help in the work team.

- In my work team, my colleagues are not reluctant to share their knowledge and experience.

- The leader or co-ordinator of my work team stands out for his/her knowledge of the task we are carrying out.

- The leader or co-ordinator of my work team is involved in the task we are carrying out as a member of the team.

Leader or co-ordinator involved with the work team

- I can obtain from the leader or co-ordinator of my team all the information I need to carry out my day-to-day work.

- The leader or co-ordinator of my work team encourages a climate of trust and co-operation among the members of the team.

- A variable part of my salary is based on my colleagues' assessment of the extent to which I co-operate with them.

- The salary of the team leader partly depends on the results that the team achieves.

Reward systems linked to knowledge sharing.

- A significant part of my salary is due to the overall results of my team.

- My company reward and compensates those team members who help their colleagues to improve and develop. 
RIJH 100320—13/8/2003_KRISHNAMURTHI—79542

\section{The International Journal of Human Resource Management}

Appendix 1 - continued

\begin{tabular}{l} 
Factor $\begin{array}{l}\text { Statements in the questionnaire } \\
\text { - I have received training about developing, presenting } \\
\text { and defending new ideas in my team, how to } \\
\text { help the others and about other aspects of }\end{array}$ \\
wraining for working in a team $\begin{array}{l}\text { My company attaches much importance to } \\
\text { training to work well in a team. }\end{array}$ \\
$\begin{array}{l}\text { - I normally have informal meetings with my team } \\
\text { mates and/or other work teams both in working } \\
\text { hours and outside the workplace. }\end{array}$ \\
$\begin{array}{c}\text { My company usually organizes social events where } \\
\text { we can have a drink after work, even parties and } \\
\text { dinners that most employees attend. }\end{array}$ \\
\hline
\end{tabular}

\section{Notes}

1 The transfer of knowledge refers to the passing of knowledge from some individuals to others. When each individual has absorbed the knowledge received in this transaction, we can say that there has been integration of the resource. When this occurs in a group of people - the self-managed work team - the output is knowledge that, while it ultimately resides in individual knowledge, has a collective character. In a certain way, it is maintained in work methods, organizational routines, shared tacit suppositions and common values.

Nonaka and Takeuchi (1995) describe the transfer and integration of knowledge as a process, which they name creation of organizational knowledge, which takes place in four phases: socialization (which means the transfer of tacit knowledge between individuals), externalization (which refers to the transformation of tacit knowledge into explicit knowledge), internalization (which refers to the integration of explicit knowledge in the minds of individuals, which then becomes tacit knowledge) and combination (meaning the integration of explicit knowledge). Other authors (e.g. Grant, 1996a; 1996b, 1997, 2001; Hedlund, 1994) describe the same process of transfer and integration of knowledge, although each author stresses different phases and uses different terms.

2 The report is available through the Internet at: http://www.kpmgconsulting.com/ kpmgsite/service/km/survey2000.html.

3 A 1997 study carried out by Ernst and Young of 431 European and US organizations in order to discover what they were doing to manage knowledge, as well as what they thought they could or should do, and what they believed the main obstacles were, indicated that, when companies began to institute the philosophy of knowledge management, they started by introducing technological capacity. Only after that did they see the human factor as essential. Moreover, that study shows that the companies are aware that they should use mechanisms other than the technological to tackle the dilemmas of knowledge management (Ruggles, 1998).

4 The statements included in the questionnaire are shown in the Appendix. 


\section{References}

Almeida, P. (1996) 'Knowledge Sourcing by Foreign Multinationals: Patents Citation Analysis in the U.S. Semiconductor Industry', Strategic Management Journal, 17(Winter Special Issue): $155-65$.

Appleyard, M.M. (1996) 'How Does Knowledge Flow? Interfirm Patterns in the Semiconductor Industry', Strategic Management Journal, 17(Winter Special Issue): 137-54.

Barney, J.B. and Wright, P.M. (1998) 'On Becoming a Strategic Partner: The Role of Human Resources in Gaining Competitive Advantage', Human Resources Management, 37(1): $31-46$.

Baron, J.N. and Kreps, D.M. (1999) Strategic Human Resources: Frameworks for General Managers. New York: Wiley.

Becker, G.S. and Murphy, K.M. (1992) 'The Division of Labour, Coordination Costs and Knowledge', Quarterly Journal of Economics, 107(4): 11-37.

Bonache, J. (1999) 'El Estudio de Casos como Estrategia de Construcción Teórica: Características’, Críticas y Defensas, Cuadernos de Economía y Dirección de la Empresa, 3: 123-40.

Borges, J.L. (1999) Autobiografía. Madrid: Ed. Ateneo.

Braun, E. and Macdonald, S. (1982) Revolution in Miniature, 2nd edn. New York: Cambridge University Press.

Cabrera, E.F. and Bonache, J. (1999) 'An Expert HR System for Aligning Organizational Culture and Strategy', Human Resource Planning, 22(1): 51-60.

Cabrera, A. and Cabrera, E. (2002) 'The Knowledge Sharing Dilemma', Organization Studies, in press.

Cannon-Bowers, J.A., Oser, R. and Flanagan, D.L. (1992) 'Work Teams in Industry: A Selected Review and Proposed Framework'. In Swezey, R.W. and Salas, E. (eds) Teams: Their Training and Performance. Norwood, NJ: Ablex, pp. 355-77.

Chaston, I. (1998) 'Self-Managed Teams: Assessing the Benefits for Small Service-Sector Firms', British Journal of Management, 9: 1-12.

Cohen, S.G. and Ledford, G.E., Jr (1994) 'The Effectiveness of Self-Managing Teams: A QuasiExperimental', Human Relations, 47: 13-43.

Cohen, W.M. and Levinthal, D. (1990) 'Absorptive Capacity: A New Perspective on Learning and Innovation', Administrative Science Quarterly, 35(1): 128-52.

Connolly, T. and Thorn, B.K. (1990) 'Discretionary Database: Theory, Data and Implications'. In Fulk, J. and Steinfield, C. (eds) Organizations and Communication Technology. London: Sage.

Cordery, J.L., Mueller, W.S. and Smith, L.M. (1991) 'Attitudinal and Behavioral Effects of Autonomous Group Working: A Longitudinal Field Study', Academy of Management Journal, 34(2): 464-76.

Cronbach, L.J. (1951) 'Coefficient Alpha and the Internal Structure of Tests', Psychonometrika, 16: 297-334.

El Sawy, O.A., Eriksson, I., Carlsson, S.A. and Raven, A. (1997) 'Shared Knowledge Creation Spaces around the New Product Development Process'. Working Paper: University of Southern California.

Eppler, M.J. and Sukowski, O. (2000) 'Managing Team Knowledge: Core Processes, Tools and Enabling Factors', European Management Journal, 18(3): 334-41.

Foner, G. (1995) 'The Hidden Injuries of Bureaucracy: Work in an American Nursing Home', Human Organization, 54: 229-37.

Garvin, D.A. and Klein, N. (1993) 'A Note on High-Commitment Work Systems', Harvard Business School, N9-693-080.

Gibson, J.W. and Tesone, D.V. (2001) 'Management Fads: Emergence, Evolution and Implications for Managers', Academy of Management Executive, 15(4): 122-33.

Goodman, P.S., Devadas, R. and Griffith-Hughson, T.L. (1988) 'Groups and Productivity: Analyzing the Effectiveness of Self-Managing Teams'. In Campbell, J.P. and Campbell, R.J. (eds) Productivity in Organizations: New Perspectives from Industrial and Organizational Psychology. San Francisco: Jossey-Bass. 
RIJH 100320—13/8/2003-KRISHNAMURTHI-79542

\section{The International Journal of Human Resource Management}

Grant, R. (1996a) 'Prospering in Dynamically-Competitive Environments: Organizational Capability as Knowledge Integration', Organization Science, 7(4): 375-88.

Grant, R. (1996b) 'Toward a Knowledge-Based Theory of the Firm', Strategic Management Journal, 17(Winter Special Issue): 109-22.

Grant, R. (1997) 'The Knowledge-Based View of the Firm: Implications for Management Practice', Long Range Planning, 30(3): 450-4.

Grant, R. (2001) 'Knowledge and Organization'. In Nonaka, I. and Teece, D. (eds) Managing Industrial Knowledge: Creation, Transfer and Utilization. London: Sage.

Hedlund, G. (1994) 'A Model of Knowledge Management and the N-Form Corporation', Strategic Management Journal, 15: 73-90.

Hilb, M. (1995) Integriertes Personal Management. Berlin: Luchterhand.

Kirkman, B.L. and Rosen, B. (1999) 'Beyond Self-Management: Antecedents and Consequences of Team Empowerment', Academy of Management Journal, 42(1): 58-74.

Kirkman, B.L. and Shapiro, D.L. (1997) 'The Impact of Cultural Values on Employee Resistance to Teams: Toward a Model of Globalized Self-Managing Work Team Effectiveness', Academy of Management Review, 22(3): 730-57.

Kirkman, B.L. and Shapiro, D.L. (2001) 'The Impact of Cultural Values on Job Satisfaction and Organizational Commitment in Self-Managing Work Teams: The Mediating Role of Employee Resistance', Academy of Management Journal, 44(3): 557-69.

Kirkman, B.L., Gibson, C.B. and Shapiro, D.L. (2001) 'Exporting Teams: Enhancing the Implementation and Effectiveness of Work Teams in Global Affiliates', Organizational Dynamics, 30(1): 12-29.

Kuemmerle, W. (1997) 'Strategic Interaction, Knowledge Sourcing and Knowledge Creation in Foreign Environments: An Analysis of Foreign Direct Investment in R\&D by Multinational Companies'. Working Paper. Boston, MA: Harvard Business School.

Lawler, E.E. (1992) The Ultimate Advantage: Creating the High-Involvement Organization. San Francisco: Jossey-Bass.

Lawler, E.E., Mohrman, S.A. and Ledford, G. (1995) Creating High Performance Organizations: Practices and Results of Employee Involvement and Total Quality Management: Practice and Results in Fortune 1000 Companies. San Francisco: Jossey-Bass.

Lazear, E.P. (1998) Personnel Economics for Managers. New York: Wiley.

Leonard, D. and Sensiper, S. (1998) 'The Role of Tacit Knowledge in Group Innovation', California Management Review, 40(3): 112-31.

Leonard, D. and Strauss, S. (1997) 'Putting Your Company's Whole Brain to Work', Harvard Business Review, 75(4): 110-21.

Lyles, M.A. and Steemsma, H.K. (1997) 'An Examination of Social Exchange and Knowledge Based Theories in Explaining IJV Performance and Survival in a Transitional Economy'. Working Paper: University of Cambridge.

Mayeroff, M. (1971) On Caring. New York: Harper \& Row.

Miles, G., Miles, R.E., Perrone, V. and Edvinsson, L. (1998) 'Some Conceptual and Research Barriers to the Utilization of Knowledge', California Management Review, 40(3): $281-7$.

Miller, D. and Shamsie, J. (1996) 'The Resource-Based View of the Firm in Two Environments: The Hollywood Film Studios from 1936 to 1965', Academy of Management Journal, 39(3): 519-43.

Moravec, M., Johannessen, O.J. and Hjelmas, T.A. (1997) 'Thumbs Up for Self-Managed Teams', Management Review, 86(7): 42-7.

Moravec, M., Johannessen, O.J. and Hjelmas, T.A. (1998) 'The Well-Managed SMT', Management Review, 87(6): 56-8.

Nicholls, C.E., Lane, H.W. and Brechu, M.B. (1999) 'Taking Self-Managed Teams to Mexico', Academy of Management Executive, 13: 15-27.

Noddings, N. (1984) Caring: A Feminine Approach to Ethics and Moral Education. Berkeley, CA: University of California Press.

Nonaka, I. and Konno, N. (1998) 'The Concept of Ba: Building a Foundation for Knowledge Creation', California Management Review, 40(3): 40-54. 
RIJH 100320—13/8/2003-KRISHNAMURTHI—79542

Zárraga and Bonache: The team environment for knowledge sharing

Nonaka, I. and Takeuchi, H. (1995) The Knowledge-Creating Company. New York: Oxford University Press.

Nonaka, I. and Teece, D. (2001) 'Introduction'. In Nonaka, I. and Teece, D. (eds) Managing Industrial Knowledge: Creation, Transfer and Utilization. London: Sage.

Pearce, J.A. and Ravlin, E.C. (1987) 'The Design and Activation of Self-Regulating Work Groups', Human Relations, 40: 751-82.

Pfeffer, J. (1999) 'Seven Practices of Successful Organizations', Health Forum Journal, 42(1): 24-7.

Ruggles, R. (1998) 'The State of the Notion: Knowledge Management in Practice', California Management Review, 40(3): 80-9.

Sanexian, A. (1991) 'The Origins and Dynamics of Production Networks in Silicon Valley', Research Police, 20: 423-37.

Sarason, S. (1985) Caring and Compassion in Clinical Practice. San Francisco: Jossey-Bass.

Stewart, G.L. and Barrick, M.R. (2000) 'Team Structure and Performance: Assessing the Mediating Role of Intrateam Process and the Moderating Role of Task Type', Academy of Management Journal, 43(2): 135-48.

Swan, J., Newell, S., Scarbrough, H. and Hislop, D. (1999) 'Knowledge Management and Innovation: Networks and Networking', Journal of Knowledge Management, 3(4): 262-75.

Szulanski, G. (1996) 'Exploring Stickiness: Impediments to the Transfer of Best Practice within the Firm', Strategic Management Journal, 17: 27-43.

Trist, E.L., Susman, G.I. and Brown, G.R. (1977) 'An Experimental in Autonomous Working in an American Underground Coal Mine', Human Relations, 30: 201-36.

Von Krogh, G. (1998) 'Care in Knowledge Creation', California Management Review, 40(3): $133-53$.

Wageman, R. (1997) 'Critical Success Factors for Creating Superb Self-Managing Teams', Organizational Dynamics, Summer: 49-61.

Wall, T.D., Kemp, N.J., Jackson, P.R. and Clegg, C.W. (1986) 'Outcomes of Autonomous Workgroups: A Long-Term Field Experiment', Academy of Management Journal, 29(2): 280-304.

Wellins, R.S., Wilson, R., Katz, A.J., Laughlin, P., Day, C.R. and Price, D. (1990) Self-Directed Teams: A Study of Current Practice. Pittsburgh: DDI.

Wright, P.M., McMahan, C. and McWilliams, A. (1994) 'Human Resources and Sustained Competitive Advantage: A Resource-Based Perspective', International Journal of Human Resource Management, 5(2): 301-26.

Yin, R. (1989) Case Study Research, Design and Methods. London: Sage.

Zaltman, G., Duncan, R. and Holbek, J. (1973) Innovations and Organizations. New York: Wiley. 


\section{Author Query Sheet}

\begin{tabular}{|l|l|}
\hline \multicolumn{2}{|c|}{ Manuscript Information } \\
\hline $\begin{array}{l}\text { Journal } \\
\text { Acronym }\end{array}$ & r-IJH \\
\hline $\begin{array}{l}\text { Volume and } \\
\text { issue }\end{array}$ & $14(7)$ \\
\hline Author name & $\begin{array}{l}\text { Zarrago and } \\
\text { Bonache }\end{array}$ \\
\hline $\begin{array}{l}\text { Manuscript } \\
\text { No. (if } \\
\text { applicable) }\end{array}$ & 100320 \\
\hline
\end{tabular}

AUTHOR: The following queries have arisen during the editing of your manuscript. Please answer the queries by marking necessary corrections at the appropriate positions on the PROOFS. Do not answer the queries on the query sheet itself. Please also return a copy of the query sheet with your corrected proofs. 
Hackman 1976 is not in references. Either add to reference list or remove from text.

Likewise Garzo and Stanwyck 1997.

Brown and MacDonald - first author spelt Braun in the references. Which is correct?

The following references do not seem to be mentioned in text. Remove?

Appleyard 1996 Kuemmerle $1997 \quad$ Lyles and Steemsma 1997

Cohen and Ledford - a 'quasi-experimental' what?

Hilb 1995 - is the book title correct? It appears to be a mixture of German and English. 